\title{
KEGIATAN SENAM OTAK DALAM MENINGKATKAN PERKEMBANGAN KOGNITIF PADA ANAK USIA DINI
}

\author{
Oleh: \\ Ni Made Ary Astuti,S.Pd \\ PAUD Mekarsari \\ aryastuti3192@yahoo.com
}

\begin{abstract}
Abstrak
Artikel ini membahas tentang bagaimana menstimulus kemampuan kognitif anak agar mampu merespon kegiatan pembelajaran yang ada dikelas menjadi lebih baik. Salah satu kegiatan yang dapat diberikan adalah dengan melakukan gerakan senam otak. Gerakan senam otak dapat diberikan pada anak usia dini di awal kegiatan atau sebelum memasuki kegiatan inti. Gerakan senam otak yang sederhana dan identik dengan gerakan menyentuh bagianbagian tubuh tertentu, akan mampu mengaktifkan energi-energi positif yang ada pada tubuh anak usia dini. Kegiatan senam otak mulai dilakukan dikelas melihat dari kondisi anak-anak di daerah $3 \mathrm{~T}$ yang agak kurang pada kemampuan kognitifnya, seperti dalam hal menanggapi perintah yang diberikan guru serta menyelesaikan tugas-tugas dalam proses pembelajaran di kelas. Mengingat perkembangan kemampuan kognitif anak-anak di daerah 3T yang dapat di katakan masih kurang, sehingga dilaksanakanlah suatu kegiatan yang bertujuan untuk meningkatkan perkembangan kognitif pada anak usia dini di PAUD Mekarsari Kecamatan Raimanuk, Kabupaten Belu NTT.
\end{abstract}

Kata Kunci: kemampuan kognitif, senam otak, anak usia dini

\section{Abstract}

The article discusses on how to stimulate students' cognitive skill to make them able to participate better during the learning activities in the class. One of the activities that can be given is brain gym movement. The brain gym movements can be given to early-aged students in the beginning of learning activities or before proceeding into the main activity. The simple movement, identical with touching certain parts of the body, can activate positive energy in the students' body. The brain gym activity was initially carried out in the class because of the students in $3 T$ region were lack of cognitive skill, like responding to teachers' instruction and finishing assignments in the learning activities. Regarding to the students' cognitive skill development in the $3 T$ region which can be said to be low, the activity was carried out in order to increase the cognitive development of the early-aged students in PAUD Mekarsari, Raimanuk subdistrict, Belu regency NTT.

Keywords: cognitive skill, brain gym, early-aged students

\section{PENDAHULUAN}

Pendidikan adalah usaha sadar dan terencana untuk mewujudkan suasana belajar dan proses pembelajaran agar peserta didik secara aktif mengembangkan potensi dirinya untuk memiliki kekuatan spiritual keagamaan, pengendalian diri, kepribadian, kecerdasan, akhlak mulia, serta keterampilan yang diperlukan dirinya, masyarakat, bangsa dan negara (Depdiknas, 2003). Pendidikan anak usia dini (PAUD) adalah suatu upaya yang ditujukan kepada anak sejak lahir sampai dengan usia enam tahun yang dilakukan melalui pemberian rangsangan pendidikan untuk membantu pertumbuhan dan 
perkembangan jasmani dan rohani agar anak memiliki kesiapan dalam memasuki pendidikan lebih lanjut. Taman kanakkanak merupakan satuan pendidikan bagi anak usia empat tahun sampai enam tahun dengan berbaagai jenis layanan sesuai dengan kondisi dan kemampuan yang ada, baik dalam jalur pendidikan formal maupun non formal (Depdiknas, 2003).

Tujuan pendidikan anak usia dini adalah membantu anak didik mengembangkan berbagai potensi baik psikis maupun fisik yang meliputi lingkup perkembangan nilai agama dan moral, fisik/motorik, kognitif, bahasa, serta sosial emosional kemandirian.

Pendidik (Guru) khususnya guru TK memiliki peran yang sangat besar dalam dunia pendidikan. Guru TK yang baik adalah guru yang mampu menciptakan suasana pembelajaran yang pakem di dalam kelas. Tetapi dalam kenyataanya hal itu sangat tidak mudah bagi guru. Apalagi siswa yang dihadapi adalah anak usia dini atau anak TK yang pemikirannya masih mengalami peralihan dari gaya berfikir yang konkrit ke gaya berfikir yang abstrak. Misalnya dalam permainan di kelas yang sukar di pahami oleh anak seperti permainan yang memerlukan konsentrasi dan daya ingat yang tinggi.

Berdasarkan dari hasil observasi yang pernah saya lakukan saat bertugas di daerah $3 \mathrm{~T}$, banyak sekali perbedaan yang dapat dilihat saat saya membandingkan PAUD yang ada di daerah tersebut dengan PAUD di daerah-daerah yang lebih maju atau daerah perkotaan. Tempat saya bertugas merupakan daerah pedesaan yang dapat dikatakan masih kental dengan adat dan budayanya yang jauh dari kondisi modern pada saat sekarang ini. Daerah tersebut terletak di desa sukabitetek, kecamatan Raimanuk kabupaten Belu. Kondisi PAUD di daerah tersebut dapat saya katakan belum sesuai dengan syaratsyarat dalam mendirikan PAUD yang layak. Walaupun kondisi bangunan sekolah yang sudah permanen dikarenakan bantuan dari pemerintah, namun alat-alat permainan yang ada dalam menunjang 5 aspek perkembangan anak usia dini dapat dikatakan masih kurang. Kondisi tersebut tentu saja memberikan batasan pada anak dalam mengembangkan aspek-aspek perkembangannnya.

Selain kondisi wilayah yang terpencil, keadaan orang tua yang sebagian besar mencari nafkah dengan bertani juga mempengaruhi pendidikan anak usia dini di daerah tersebut. Kesibukan orang tua bekerja membuat kesadaran mereka mengantar anak-anak kesekolah juga sangat kurang, sehingga banyak anak-anak yang lebih memilih pergi ke kebun bersama dengan orang tua mereka. Seringnya anak-anak bolos sekolah sudah tentu berpengaruh pada perkembangan kognitifnya yang juga jarang diasah. Selain dari wilayah dan kontribusi dari orang tua juga asupan makanan yang sangat sembarangan. Makanan yang anak-anak usia dini konsumsi bisa dikatakan tidak mampu memenuhi asupan gizi yang sudah seharusnya mereka dapatkan. Contohnya saja anak-anak mampu menghabiskan berbungkus-bungkus penyedap makanan yang mengandung msg yang berbahaya bagi tubuh. Tentu saja hal tersebut dapat berpengaruh pada aspek-aspek perkembangannya khususnya aspek perkembangan kognitif. Hal terakhir dan yang paling penting adalah minat dari anak-anak itu sendiri. Seperti yang kita ketahui dunia anak adalah dunia bermain. Maka sudah pasti respon mereka terhadap kegiatan bermain yang menyenangkan akan lebih besar jika dibandingkan dengan kegiatan pembelajaran yang membosankan. Mengingat kondisi sekolah di PAUD mekarsari yang monoton dan kurang menarik maka sudah tentu membuat anak-anak usia dini menjadi malas untuk datang ke sekolah.

Berdasarkan permasalahan diatas, Maka sebagai guru di daerah 3T saya berusaha memberikan pengertian pada 
orang tua betapa pentingnya pendidikan sejak dini. Selain itu untuk mengatasi permasalahan-permasalahan yang ada guru sebagai fasilitator harus memfasilitasi peserta didik dengan keterampilan untuk membangkitkan semangat anak dalam mengikuti proses pembelajaran. Sedangkan kita ketahui bahwa setiap anak memiliki karakteristik berbeda terutama dalam hal cara bermain dan menangkap informasi sederhana, oleh karena itu diperlukan metode, model, trik, alat bantu dan media pembelajaran agar anak mampu menerima dan memahami pembelajaran di kelas. Guru dituntut untuk mengembangkan strategi pembelajaran yang dapat membangkitkan dan memotivasi anak untuk belajar dengan aktif dan kreatif serta meningkatkan aspekaspek perkembangan anak khususnya pada aspek perkembangan kognitif. Salah satu kegiatan yang saya berikan pada saat mengajar di PAUD mekarsari adalah kegiatan senam otak.

\section{Senam Otak}

Banyak ahli mengatakan anak terlahir dengan kemampuan dan kreativitas yang berbeda-beda. Kreativitas anak dapat berkembang sesuai dengan kemampuannya, untuk itu orang tua dan guru perlu mengetahui metode apa yang hendaknya sesuai diberikan pada anak yang sesuai dengan kreativitas dan perkembangannya. Dengan metode bermain melakukan gerakan-gerakan yang menarik (senam otak), sudah tentu akan menstimulus otak anak menjadi lebih baik dalam menangkap proses pembelajaran di kelas.

Senam otak adalah salah satu teknik relaksasi dalam mengajar (indoor ataupun outdoor) dengan melakukan gerakangerakan yang sehat, alami dan sederhana untuk menghadapi ketegangan dan tantangan pada diri sendiri dan orang lain dalam penyampaian pesan pelajaran agar tercapai tujuan yang diharapkan. Menurut Dennison (2012:45) adapun langkah- langkah senam otak dapat dilakukan dengan diawali minum air putih yang merupakan pembawa energi listrik yang sangat baik guna memperlancar aliran pada tubuh, melakukan gerakan burung hantu guna melepaskan ketegangan tengkuk dan bahu untuk meningkatkan kemampuan perhatian dan ingatan, gerakan mengaktifkan tangan dengan memperpanjang otot-otot dada atas dan bahu guna memperlancar gerakan motorik kasar dan halus, pijat daun telinga guna melatih memusatkan perhatian pada pendengaran, memijat titik positif pada dahi yang berfungsi sebagai tempat pikiran logis, menguap berenergi merupakan refleks pernapasan alami yang meningkatkan peredaran udara ke otak dan merangsang seluruh tubuh.

Menurut Hannaford dalam

Educational Kinesiology keunggulan dari senam otak adalah mampu menstimulus dan memaksimalkan fungsi otak. Selain itu senam otak dapat menyegarkan otak dan membuat kita berpikir lebih positif. Senam otak juga bermanfaat untuk memaksimalkan potensi akademik, sosial, dan fisik. Bisa dikatakan dapat meredakan stress, meningkatkan kesadaran diri akan lingkungan sekitar, dan menjaga kebugaran tubuh.

Salah satu tingkat pencapaian perkembangan yaitu kemampuan kognitif untuk anak usia dini memang membutuhkan metode dan media pembelajaran yang dapat memotivasi anak, untuk menunjukkan aktivitas dan kemampuannya lebih giat dan semangat lagi. Menurut Drever (dalam Fawzia Aswin Hadis, 1996) disebutkan bahwa "kognitif adalah istilah yang umum yang mencakup segenap model pemahaman yakni persepsi, imajinasi, penangkapan makna, penilaian dan penalaran". Sedangkan menurut Piaget (Hetherington \& Parke, 1975) menyebutkan bahwa "kognitif adalah bagaimana anak beradaptasi dan menginterprestasikan objek dan kejadian-kejadian disekitarnya. 
Piaget memandang bahwa anak memainkan peran aktif dalam menyusun pengetahuannya mengenai realitas anak tidak pasif menerima informasi”. Salah satu bagian dari kemampuan kognitif adalah kemampuan dalam memecahkan masalah-masalah sederhana seperti menyelesaikan tugas yang diberikan guru serta kemampuan dalam menyimak dan melaksanakan perintah yang diberikan guru.

Janice (dalam Aisyah 2008) telah mengorganisasi sejumlah pengembangan konsep yang muncul secara sistematis melalui beberapa program pengembangan kognitif pada anak usia dini. Bentuk adalah salah satu konsep paling awal yang harus dikuasai. Anak dapat membedakan benda berdasarkan bentuk lebih dulu sebelum berdasarkan ciri-ciri lainnya. Mengenal bentuk merupakan konsep awal yang perlu dikuasai anak yang didalamnya terdapat indikator dalam hal mengklasifikasikan benda berdasarkan bentuk. Dalam proses pembelajaran di TK, seorang guru memiliki peran yang sangat penting dalam melatih keterampilan, dan menciptakan suasana kelas yang pakem, sehingga para guru dituntut memiliki kualifikasi dan kompetensi tertentu agar proses belajar dan pembelajaran dapat berlangsung dengan efektif dan efisien. Adanya motivasi dan minat belajar yang tinggi serta pemanfaatan metode dan media pembelajaran yang tepat akan menjadikan siswa mudah dalam memahami apa yang disampaikan oleh guru. Selama ini kemampuan kognitif untuk anak usia dini khususnya di PAUD Mekarsari bisa dikatakan kurang tercapai secara optimal, hal ini dikarenakan pembelajaran yang terjadi di dalam kelas kurang menggunakan kegiatan awal yang menyenangkan. Hal tersebut membuat siswa malas dan kurang berminat dalam melakukan kegiatan-kegiatan inti yang bertujuan untuk mengasah kemampuan kognitif anak.
Tetapi dengan saya mencoba memulai kegiatan senam otak sebelum kegiatan pembelajaran inti berlangsung, maka saya dapat melihat antusias, semangat dan respon anak menuju kegiatan pembelajaran berikutnya menjadi lebih baik dari sebelumnya. Anak terlihat senang mengikuti gerakan-gerakan sederhana dan masih baru atau belum pernah mereka lakukan sebelumnya. Mungkin bagi anak-anak di PAUD mekarsari gerakan-gerakan tersebut terasa lucu mereka praktekan sambil bermain dan tertawa.

\section{PEMBAHASAN}

Pada pembahasan kali ini saya mencoba untuk menguraikan beberapa gerakan-gerakan senam otak sederhana yang dapat dilakukan pada anak usia dini menurut Dennison (2012:45) sebagai berikut.

- minum air putih yang merupakan pembawa energi listrik yang sangat baik guna memperlancar aliran pada tubuh,

- melakukan gerakan burung hantu guna melepaskan ketegangan tengkuk dan bahu untuk meningkatkan kemampuan perhatian dan ingatan,

- gerakan mengaktifkan tangan dengan memperpanjang otot-otot dada atas dan bahu guna memperlancar gerakan motorik kasar dan halus,

- pijat daun telinga guna melatih memusatkan perhatian pada pendengaran,

- memijat titik positif pada dahi yang berfungsi sebagai tempat pikiran logis,

- menguap berenergi merupakan refleks pernapasan alami yang meningkatkan peredaran udara ke otak dan merangsang seluruh tubuh. 
Pembahasan dari hasil kegiatan senam otak pada anak usia dini di PAUD Mekarsari ini menyangkut tentang peningkatan kemampuan kognitif dalam kegiatan pembelajaran sehari-hari. Berdasarkan pada permasalahan yang terjadi pada anak-anak di PAUD mekarsari yang telah saya uraikan di pendahuluan seblumnya, maka hasil yang saya lihat beberapa minggu kedepannya adalah sebagai berikut.

- Pada awal saya mengajar di PAUD mekarsari, respon orang tua terhadap pendidikan anak usia dini ternyata masih sangat minim. Sehingga disitu saya mencoba memberi pengertian pada orang tua bahwa pendidikan anak usia dini sangat penting. Keadaan dimana jumlah anak yang awalnya kehadiran mereka dalam 1 hari dan 1 kelas adalah 10 anak, perlahan mulai meningkat menjadi $15-20$ anak.

- Antusias anak-anak PAUD Mekarsari datang kesekolah dan mengikuti pembelajaran di sekolah yang pada awalnya harus saya jemput, mulai memiliki kesadaran sendiri untuk datang belajar ke sekolah. Dengan mengajak anak melakukan gerakan-gerakan senam otak membuat anak semangat setiap harinya kesekolah.

- Dalam tubuh manusia ternyata terpendam energi dan potensi yang dapat kita aktifkan dengan gerakan dan sentuhan yang cukup sederhana untuk meningkatkan daya belajar kita. Gerakan tersebut dinamakan dengan senam otak. Senam otak mampu memberi energy positif pada anak usia dini. Anak-anak di PAUD Mekarsari yang pada awalnya kurang focus ketika diberikan tugas pelan-pelan menjadi lebih focus menerima dan mengerjakan perintah dari saya.
Kondisi dimana anak merasa lebih nyaman dan memiliki energy positif yang lebih baik setelah melakukan kegiatan senam otak, membuat saya lebih mudah memberitahukan nilai-nilai moral dan pengetahuan dalam pembelajaran. Saya sebagai guru 3T mencoba memberitahukan pada anak-anak tentang makanan yang baik dan tidak baik mereka konsumsi. Hal ini tentu saja sangat berpengaruh pada perkembangan otak serta kogitif anak usia dini di PAUD Mekarsari.

Otak sebagai pusat kegiatan tubuh akan mengaktifkan seluruh organ dan sistem tubuh melalui pesan-pesan yang disampaikan melewati serabut saraf secara sadar maupun tidak sadar. Pada umumnya otak bagian kiri bertanggung jawab untuk pergerakan bagian kanan tubuh dan sebaliknya. Dengan demikian betapa pentingnya kegitan senam otak dalam menunjang perkembangan anak usia dini.

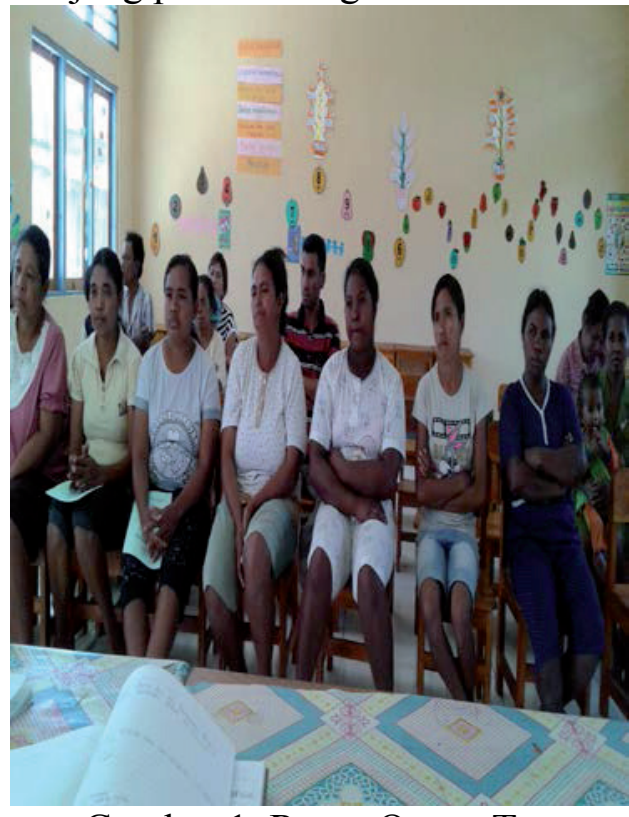

Gambar 1. Rapat Orang Tua 




Gambar 2. Rapat Orang Tua

Gambar 01 dan 02 di atas adalah salah satu bukti kegiatan yang saya lakukan di PAUD Mekarsari untuk memberikan pengertian pada orang tua mengenai betapa pentingnya pendidikan untuk anak usia dini. Komitmen dari orang tua untuk mengantar anaknya kesekolah sebelum bekerja kekebun sangat ditekankan pada saat itu. Hal ini dikarenakan kondisi dimana anak jarang pergi kesekolah akan membuat anak ketinggalan dalam mengejar pembelajaran sehingga dapat menghambat perkembangan kognitif anak usia dini.

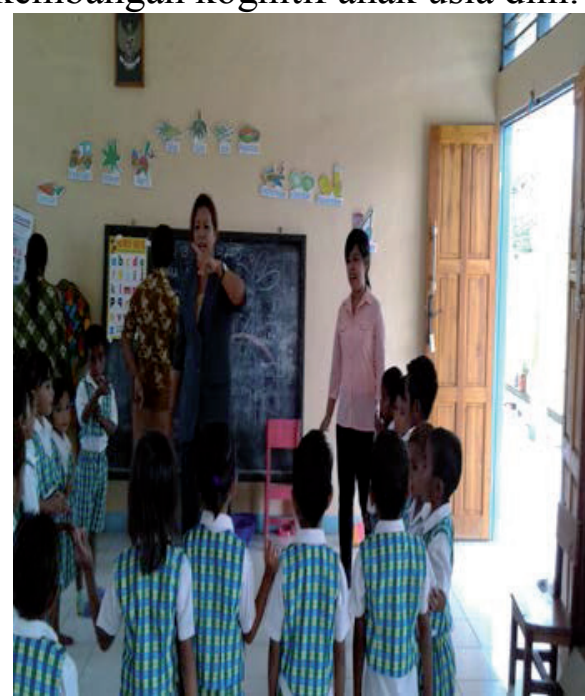

Gambar 3. Kegiatan Senam Otak

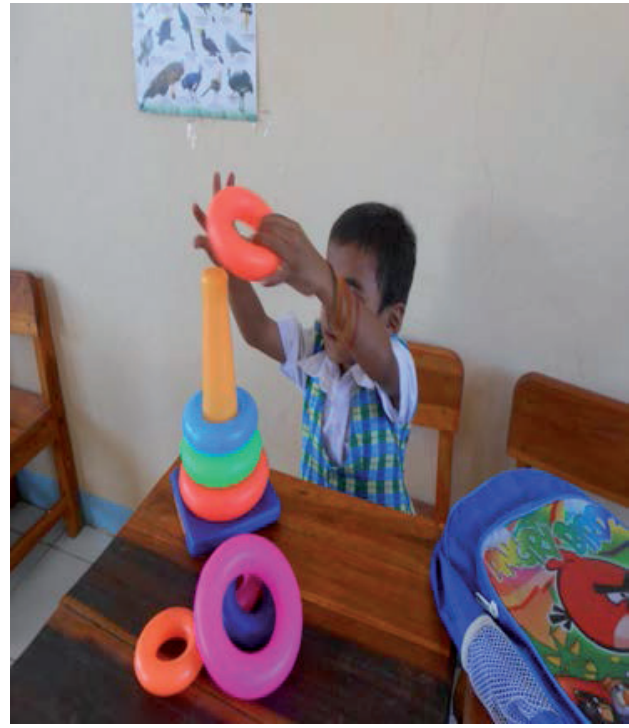

Gambar 4. Pembelajaran di Kelas

Kegiatan pada gambar diatas menjelaskan tentang bagaimana kegiatan senam otak tersebut berlangsung bersama guru-guru dan anak-anak PAUD Mekarsari. Manfaat dari senam otak sangat terlihat jelas dari antusias anak-anak mengikuti satu demi satu gerakan yang di perintahkan. Implementasi dari kegiatan senam otak terlihat jelas pada salah satu anak yang awalnya sama sekali tidak mau mengerjakan tugas yang diberikan, namun pelan-pelan anak tersebut mau melaksanakan kegiatan yang diberikan dengan hasil yang baik.

\section{KESIMPULAN}

Berdasarkan dari kegiatan yang saya laksanakan di daerah 3T dengan mencoba melaksanakan kegiatan senam otak, maka melalui artikel ini dapat saya simpulkan bahwa perkembangan anak usia dini khususnya perkembangan kognitifnya dapat kita kembangkan dengan sebaikbaiknya melalui kegiatan, metode, serta permainan yang tepat. Metode yang dapat kita lakukan dapat dimulai dari pendekatan terhadap keluarga serta pengetahuan terhadap lingkungan tempat tinggal anak agar guru dapat menyesuaikannya di sekolah. Setelah kondisi dan keluarga yang mendukung $100 \%$ pembelajaran, maka kita dapat 
mencari tau kegiatan baru yang menarik bagi anak usia dini salah satunya yaitu kegiatan senam otak. Hal ini sangat sesuai mengingat tingkat aspek perkembangan kognitif di daerah tempat saya bertugas sangat kurang khususnya pada anak usia dini.

\section{DAFTAR PUSTAKA}

Dennison Paul \& Gail E. Dennison. 2012. Brain Gym (Senam Otak) Gerakan Sederhana untuk Belajar dengan Keseluruhan Otak. Jakarta: Penerbit PT Gramedia Widiasarana Indonesia.

Depdiknas, 2003. Modul Penelitian Pengelolan dan Tenaga Pendidik Kelompok Bermain. Jakarta: Departemen Pendidikan Nasional.

http://elis braingym.pdf:21 19.36

http://publikasiilmiah.ums.ac.id.pdf:21

$\underline{20.06}$ 